\title{
History and Problems of Education in Afghanistan
}

\author{
Mehtarkhan Khwajamir ${ }^{1 \mathrm{a}}$ \\ ${ }^{1}$ Meram,Konya, 42000, Turkey
}

\begin{abstract}
The formal education institutions in Afghanistan never existed from its establishment (1747) until 1875. Despite that the foundation of modern education was laid in 1875, the number of established schools didn't exceed four until 1919. King Amanullah Khan (1919-1929) made the primary schools compulsory to all, for the first time he opened schools for girls and sent some female students to Turkey for education. This led to his exile from Afghanistan. From 1929 to 2001 there were enhancements in the educational fields although some obstacles emerged especially to female educators during some periods. The education is better today in comparison with previous periods; but there are still some problems in this field. The aim of this paper is to evaluate briefly the important developments which happened in the education system from the 4th century until today and the problems that have impeded the education in different periods in Afghanistan. This article focuses on the official education institutions from the establishment of Afghanistan (1747) until today. History of education in Afghanistan is ranked according to periods and the positive and negative developments in each period are also briefly discussed.
\end{abstract}

Keywords. Afghanistan; education; education history; problems.

\section{Introduction}

\subsection{The History of education in Afghanistan}

When Islam entered to Afghanistan there was not any central administration in this geography. The north, south, east and west of the country was ruled by several local rulers who had different languages and cultures [7]. Zoroastrianism, Buddhism and Hinduism religions and those religious educations were dominant in Afghanistan before Islam [7, 6]. With the spread of Islam in the mentioned lands in 7th century, Islamic education has taken

\footnotetext{
a Corresponding author: mehterhan_4@windowslive.com
} 
the place of other religious educations while Islam has taken the places of other religions $[6,11]$. Cities such as Balkh, Ghazni, Herat and Ghur that are located today within Afghanistan borders, became the educational centres (Istakhri, 2004; 8]. Thus there were 3000 students in Dahhak bin Muzahhim's (d. 723) school [8]. Likewise in the Abbasid period there were only in Balkh existed 400 madrasas and 900 schools for children [14]. It is known that there were more than 50 madrasas which were built by the government and also about 50 by the people in Mahmud of Ghazni (998-1030) era [4]. Before 7th century (hijri) there were 359 madrasas and Islamic monastery (takka) in Herat [13]. The Ghurids government (1000-1215) also had given value to the education and scholars. In this period the education continued in madrasas and new madrasas were established in Gazni, Balhk, Herat, Bukhara [10]. In the era of the Timurid dynasty a lot of madrasas as well as Mosques were established.

After the entrance of Islam to Afghanistan the positive science education was not neglected besides the emphasis on religious education. Indeed Ebu Nasr Al-Farabi (Alpharabius) (d. 950), İbn Sina (Avicenna) (d. 1037), Ebu Reyhan el-Biruni (d. 1061) who had given direction to the word of knowledge by their skills and knowledge got their education in this region.

The formal education institutions in Afghanistan never existed from its establishment (1747) until 1875. Amir Shir Ali Khan Amir of Afghanistan (ruled 1868-78) had built for the first time in Afghanistan history two formal schools that underlined the modern education. One of those was for the civilian and the other was a military school [1].

Later, additional two schools were built in the period of King Habibullah Khan (190119) that were appropriately similar to today's modern education system. One of these schools was founded in 1903 and started its education with only 10 Afghan and Indian educators. It was named Lisa Habibia (Habibia High School). The second one which was built in 1909 was named Maktab-e Harbiya [11]. Despite that the foundations for modern education was laid in 1875, the number of established schools didn't exceed the number four until 1919.

The third and the biggest development in education took place after 1919. King Amanullah Khan (ruled 1919-29) made the primary schools compulsory to all [12]. In this period for the first time a Ministry of Education was established, the number of high schools increased, German and French teachers were also employed in Kabul high schools as well as Afghan teachers. In this period for the first time schools were opened at the outside of the capital too. The numbers of primary schools have increased to 322. Hundreds of students have been sent by the Ministry of Education to study in Russia, Italy, Germany as well as Turkey. In 1921 schools were opened for girls and some female students were sent to Turkey for education [6]. The opening of schools for girls and female students being sent to Turkey by Amanullah Khan led to a reaction of the scholars on the ground of that it is contrary to Sharia. In 1923 the scholars requested from Amanullah Khan the closing of the girls' schools; because according to them, women can only be educated by their intimates in their own homes. It is not permitted for female students to study outside of their homes. Although, Amanullah Khan tried to convince the scholars that there is no ruling in Islam that forbids women from studying and showed them examples from other Islamic countries such as India, Mecca, Medina, Egypt, Damascus and Baghdad, it was in vain. Thus, he closed the girls' schools for a while then reopened them [1]. The opening of girl schools and sending girls to Turkey for education led finally to the exile of King Amanullah Khan from Afghanistan in 1929 [2].

In 1929 Habibullah Kalakany (ruled 9 months in 1929) had closed the girls' schools and recalled the female students who were sent abroad. He also closed schools that were opened 
by foreign countries such as Germany and France etc [11]. During Nadir Shah reign (ruled 1929-33) girls' schools were reopened and new schools were established. The first core of higher education is Kabul Medical Faculty which was established in 1932. The founding dean of this faculty was Professor Doctor Rifk1 Kamil who came from Turkey and in the next year other Turkish professors also came from Turkey to teach in this faculty. This faculty with five others faculties were founded before the establishment of the universities in Afghanistan [3].

During the reign of Zahir Shah (ruled 1933-73), the development of education and training has continued albeit slowly [1]. During this period, many students were sent to foreign countries such as Germany, France, the US, India and many others and a lot of new schools were established [11]. In 1946 Kabul University was established as the first university in Afghanistan. This was followed by the establishment of other faculties and universities [3].

From the occupation of Afghanistan by the Soviet Union in 1979 until their withdrawal in 1989 and collapse of the communist regime in Afghanistan in 1992, the education and training of students continued. However, education in this period was limited to the cities which were in the control of the central government [11]. There was no formal education in many cities that were out of the central government's control. About five million Afghan Refugees in Pakistan and Iran and those who opposed the central government have established some schools and tried to continue their own education. In Pakistan, refugees have established some universities besides schools [1].

The Taliban regime (ruled 1996-2001) banned education of females and closed all girls' schools except the Kabul Medical Faculty. They left the medical faculty open because female patients were permitted to be examined only by female doctors. For this reason Taliban also had not banned women from working as doctors and nurses but they banned women working in all other areas. In this period, the numbers of religious madrasas have increased and almost all other schools have been transformed into madrasas. In 2001, the Taliban regime issued an educational law and pointed out in the mentioned law's second article that education is an equal right for all Afghan citizens. Also in the third article it is stated that women education will be regulated by a special law in accordance with the Sharia [9]. However, this special law about female education was never issued after that onwards.

During Hamid Karzai's era (ruled 2001-14) according to the report which was published by the Afghanistan Ministry of Education in 2012, 10.5 million students studied in 16,600 schools and training centers. $\% 38$ of them consisted of female students. Likewise, 770,000 seniors studied in 30,000 literacy courses. \%62 percent of them were also women (Maarif, Volume, 170). Today there are about 30 state universities and about 100 private universities and colleges in Afghanistan.

\subsection{The educational problems}

We can list the problems of education and training in Afghanistan briefly as the following:

1. The delay of modern education and training in Afghanistan.

2. The resistance of clergy to the education of women during the reign of Amanullah Khan.

3. Closing of girls' schools and foreign country schools in the era of Habibullah Kalakany

4. The war which started with the Soviet Union invasion and continued after that as a long civil war in Afghanistan.

5. The closing of girls' schools and transformation of other schools to madrasas in the era of the Taliban regime. 
6. The attempts of the Taliban organization to stop the girls from attending schools by killing the teachers, burning the schools and poisoning of students etc.

7. The economic problems of the Afghan people.

8. Lack of school buildings.

\section{Conclusion}

After the entrance of Islam to Afghanistan, pre-Islamic religious education was replaced by Islamic religious education. However, education in positive science was not neglected besides the emphasis on religious education. Despite that the foundations of modern education was laid in 1875, the number of established schools didn't exceed only four until 1919. King Amanullah Khan (ruled 19191-1929), gave importance to education, but some Afghan clergymen opposed him especially due to female education issues. Despite this, there have been significant developments in education system during this period. In the following periods, progress continued in the education field more or less. From 1929 to 2001 there were enhancements in the educational fields although some obstacles emerged especially to female education in some periods. In recent times the most serious harm was caused to the education institutions by the Taliban regime. They banned the education of women and shut down all the girls' schools. Education is better today in comparison to the previous periods; but there are still some problems that still remain in this field.

\section{References}

1. Andishmand, M. E. Maarif-e Asri-yi Afghanistan (1903-2010). Kabul: Entesharat-e Maywand, (2011).

2. Ataee, M.I. Tarih-e muasir-i Afghanistan, (Translator to Persian. J. Kamgar), Kabul: Bingah Entesharat-e Matbaa-yi Maywand, (2005).

3. Committee. Maarif-e Afghanistan dar Penjah Sal-e Akheer. Kabul: Shuba-e Tabaa'tiye Mudiriyat-e Umumi-yi Nasharat-e Pohantun-e Kabul, (1968).

4. Eeman, bt. S. b. H., el-Hayatu'l-ilmiyya fee Balkh khelala'l-fitrate (205-617/8201220), (Unpublished master's thesis), Jameatu Ummi'l-Qura, Saudi Arabia, (2013).

5. Estakhri, I. b. M. F., Al-Masâlik va'l-mamâlik. Beyrut: Daru Sâdir, (2004).

6. Ghubar, M.G.M. Afghanistan der mesir-e tarih. (vol.I.), Tahran: Entesharat-e Jumhoori, (1989)

7. Habibi, A. Tarih-e Afghanistan ba'd az Islam. İran: Entisharat-e Afsoon, (2002).

8. Hamavi, A. A. Y. b. A. Mu'jamu'l-buldân. Beyrut: Daru Sâdir, (1995).

9. Jarida-e Rasmi (Afghanistan Official Gazzete), 2001.

10. Joozjani, A. M. O. b. S. Tabaqat-e Naseriyya. Kabul: Pohanee Matbaa, (1964).

11. Kamgar, J., Tarih-e Maarif-e Afghanistan. Kabul: Entesharat-e Maywand, (2008).

12. Nizamname-e Asasi-ye Devlet-i Alliya-yi Afghanistan, 1923.

13. Sa'îdî, A. "Bar-rasî-yi vad'iyyat-e ictimâ'i-ye Gaznî-ye asr-1 Ghaznaviyyan", Ghaznî bister-e tamaddun-e şarq-1 Islami, Mecmû'a mekalat, Tahran: Entisharat-1 Irfan, (2014).

14. Vaiz-i Balkhî, A. B. A. b. O.b. M. b. D. Fazâil-u Balkh, (Translate to Persian by Abdullah M. b. H. H. B. Edited By Habibi, A.). Tahran: Jangalak, (2009). 